\title{
Detection, Identification, and Quantification of SF6 Point-Source Emissions Using Hyper-Cam LW Airborne Platform
}

\author{
Mariusz Kastek, Krzysztof Firmanty \\ Military University of Technology, Institute of Optoelectronics, 2 gen. S. Kaliskiego str., 00-098 Warsaw, Poland
}

\section{Benjamin Saute, Jean-Philippe Gagnon, Martin Lariviere-Bastien}

Telops, 100-2600 St.-Jean Baptiste Ave. Quebec City, QC G2E 6)5, Canada

\author{
Daniel Pawelski \\ Technovis Sp. z 0.0., 20B Towarowa str., 10-417 Olsztyn, Poland
}

\begin{abstract}
Detection, identification, and quantification of greenhouse gases is essential to ensure compliance with regulatory guidelines and mitigate damage associated with anthropogenic climate change. Passive infrared hyperspectral imaging technology is among the solutions that can detect, identify and quantify multiple greenhouse gases simultaneously. The Telops Hyper-Cam Airborne Platform is an established system for aerial thermal infrared hyperspectral measurements for gas survey applications. In support of the Hypercam, is developing a suite of hyperspectral imaging data processing algorithms that allow for gas detection, identification, and quantification in real-time. In the Fall of 2020, the Hyper-Cam-LW Airborne platform was flown above a validated SF6 gas release system to collect hyperspectral data for gas quantification analysis. This measurement campaign was performed to document performance of the Hyper-Cam gas quantification capabilities against known quantities of released gas.
\end{abstract}

\section{Introduction}

Detection, identification, and quantification of greenhouse gases and other environmental pollutants is a measurement challenge of ever-increasing importance to the efforts to mitigate the effects of Climate Change. Thermal infrared hyperspectral imaging is well-suited to these tasks, yielding an information-rich data product containing a continuous, high-resolution infrared radiance spectrum for each pixel in the FPA detector. This three-dimensional data product is often referred to as a hypercube and can be used to characterize the spatial distribution of chemical species within a large scene. When combined with

Autor korespondujący:

Mariusz Kastek, mariusz.kastek@wat.edu.pl

Artykuł recenzowany

nadesłany 01.07.2021 r., przyjęty do druku 19.08.2021 r.
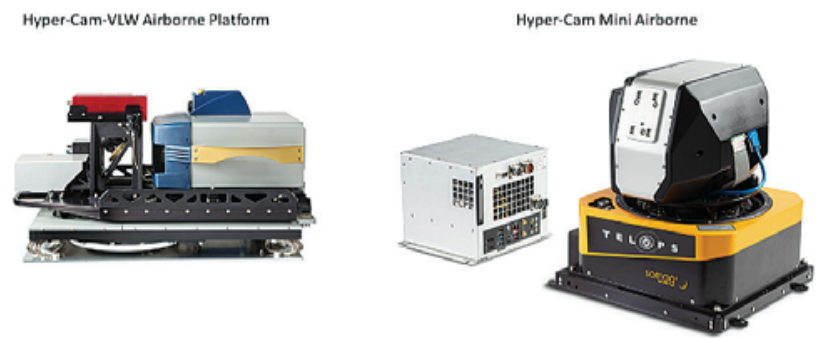

Fig. 1. Telops Hyper-Cam LW Airborne Platform (left) and the new Hyper-Cam Airborne Mini (right)

Rys. 1. Platforma lotnicza Telops Hyper-Cam LW (po lewej) i nowa Hyper-Cam Airborne Mini (po prawej)

an aerial survey platform, thermal infrared hyperspectral imaging represents a powerful tool for monitoring for fugitive gas emissions over wide areas.

Telops has been designing and manufacturing high-performance thermal infrared hyperspectral imaging systems for over 20 years, primarily through the commercially available Hyper-Cam line. The Hyper-Cam is a passive, FTIR-based thermal infrared hyperspectral imaging system that allows for the generation of $320 \times 256$ pixel hypercubes with user-selectable spectral resolution down to $0.25 \mathrm{~cm}^{-1}$ [1]. Installation of the Hyper-Cam sensor into an aircraft is enabled by the Hyper-Cam Airborne Platform. The Airborne Platform is 
a stabilization platform equipped with GPS and IMU technology for georeferencing and tracking aircraft movement in flight. The data collected by the positioning sensors is utilized to control an image motion compensation mirror that allows for high-quality measurements of a specific target or pre-determined area.

While the current generation of Hyper-Cam and Airborne platform have been successfully deployed on hundreds of measurement campaigns, Telops has launched the next-generation airborne hyperspectral system, the Hyper-Cam Airborne Mini. The Hyper-Cam Airborne Mini maintains the flexibility and high-performance measurement capabilities of the original Hyper-Cam while significantly reducing instrument footprint and weight ( $<25 \mathrm{~kg}$ for optical head and processing box). This allows operation from a significantly increased population of aerial platforms compared to the original Hyper-Cam Airborne Platform.

Telops has utilized the legacy Hyper-Cam Airborne system to aid in development of automated hyperspectral data exploitation processes that can be executed in real-time to quickly provide quantitative results. The collected data is analyzed by robust quantitative algorithms utilizing a full radiative transfer model and several assumptions or measurements of scene parameters. This report presents the results of a measurement campaign performed in Fall 2020 designed to validate the performance of Telops data processing algorithms for aerial gas detection, identification, and quantification tasks using data acquired by legacy Hyper-Cam LW Airborne system with the overall goal of implementation on the new Hyper-Cam Airborne Mini platform.

\section{Experimental}

The Fall 2020 measurement campaign was performed over the Telops factory in Quebec City. On the ground, a quantitative gas release system was constructed consisting of a cylinder of compressed SF6 and a variable mass flow meter as shown in Fig. 2. This system was used to release a series of gas "puffs" of known mass by monitoring the gas flow rate and the length of time of the release.

The experimental design called for the production of spatially separated gas clouds of known mass which was to be accomplished by releasing gas to form a cloud, turning off the gas to allow the cloud to drift with the wind, and then releasing gas again to form another cloud. Unfortunately, due to lower than

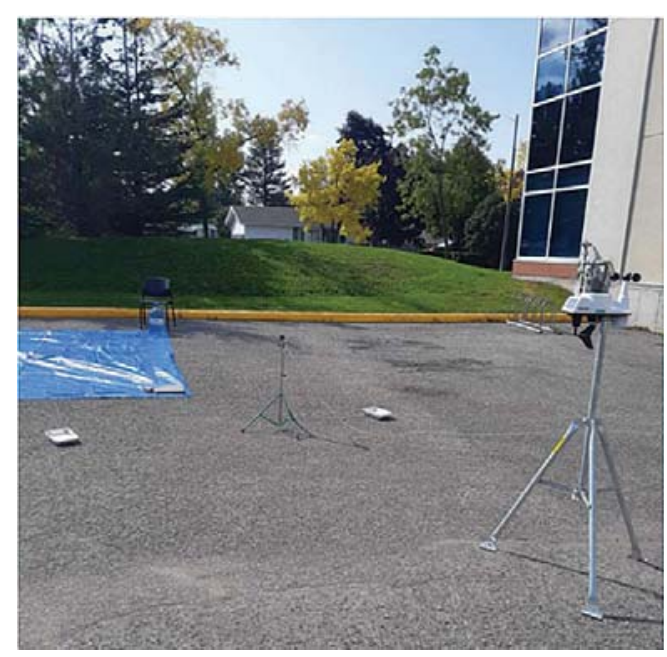

Fig. 2. Validated SF6 gas release system (center), blue tarp for spectral reference (left), and weather station (right)

Rys. 2. System uwalniania gazu SF6 (w środku), niebieska plandeka dla odniesienia spektralnego (po lewej) i stacja meteorologiczna (po prawej) predicted wind speeds on the day of the measurement campaign, the dissipation of the initial gas clouds was insufficient to yield clear separation from the next gas cloud. Despite these limitations, data collection and analysis proceeded as planned.

With the quantitative gas release system validated and operational, the Hyper-Cam LW Airborne Platform was installed into a small aircraft and flown over the gas release site at an altitude of $850 \mathrm{~m}$ AGL. Infrared hyperspectral data collection and quantification were performed in real-time and gas quantification maps were produced in the dead-time prior to aircraft landing.

\section{Principles of gas quantification}

The first step toward quantifying gas emissions is to detect and identify the substance. This is accomplished using Telops Reveal ADI software which allows for chemical imaging of multiple gases simultaneously on an interactive interface (refer to Fig. 3). The Reveal ADI software uses a powerful and specialized generalized likelihood ratio algorithm (GLRT) [1-3].

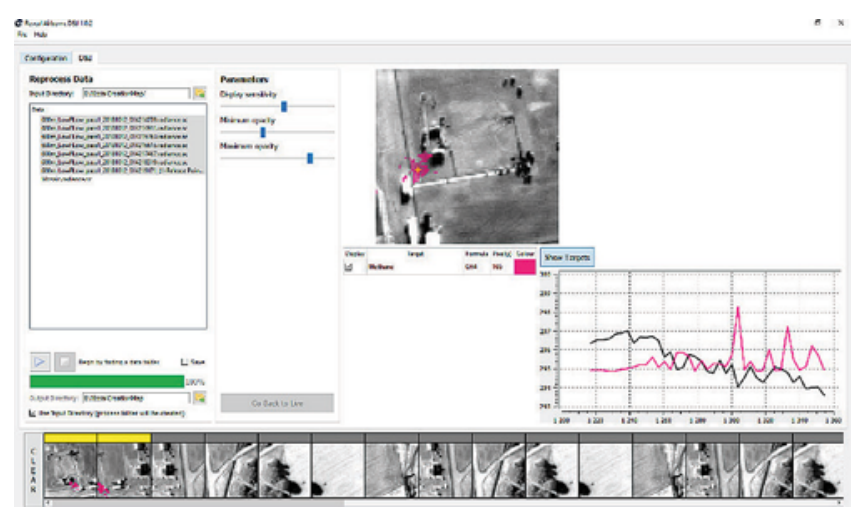

Fig. 3. Reveal Airborne Detect and Identify (D\&l) Software Rys. 3. Ekran oprogramowania Reveal Airborne Detect and Identify (D\&I)

The second step is to produce the column path concentration map of the gas plume (in units of $p p m \cdot m$ ) from the acquired spectral radiance datacube. This is accomplished using a rapid gas quantification retrieval algorithm $[4,5]$ located between object (background. At its core lies a physical radiative transfer model. More precisely, the total radiation from a pixel in the gas plume measured by the camera can be expressed as:

$$
L_{g a s}=\tau_{g a s} \cdot \tau_{a t m} \cdot L_{b k g}+\tau_{a t m} \cdot\left(1-\tau_{g a s}\right) \cdot L\left(T_{g a s}\right)+\left(1-\tau_{a t m}\right) \cdot L_{a t m}
$$

Whereas the total radiation from a pixel outside the gas plume is:

$$
L_{r e f}=L_{b k g} \cdot \tau_{a t m}+\left(1-\tau_{a t m}\right) \cdot L_{a t m}
$$

where: $L_{\text {gas }}$ - radiance measured by the camera, $\tau_{\text {gas }}$ - transmittance of the gas, $\tau_{\text {atm }}$ - transmittance of the atmosphere, $\left(1-\tau_{\text {gas }}\right) \cdot L\left(T_{\text {gas }}\right)$ - radiance of the gas plume at the temperature of the gas $T_{g a s}$, $L_{\text {atm }}$ - radiance emitted by the atmosphere, $L_{\text {ref }}$ - radiance from a pixel outside of the gas plume.

By making assumptions such as a constant plume temperature across the column path, a localized gas plume and a gas plume temperature equal to the atmospheric temperature, it is possible to solve for $\tau_{\text {gas }}$ and thus obtain the gas concentration values.

$$
\tau_{\text {gas }}=\frac{L_{\text {gas }}-L\left(T_{a t m}\right)}{L_{\text {ref }}-L\left(T_{a t m}\right)}
$$

It is worth noting that the algorithm uses the brightness temperature of strong water vapor spectral lines to estimate 
the atmospheric temperature $\left(T_{\text {atm }}\right)$. A principal component analysis $(\mathrm{PCA})$ is performed on the image to help select background pixels and thus estimate $L_{r e f}$ Homogeneous media are characterized by constant spectral absorption coefficients. Consequently, the light transmittance through a layer of such media having a thickness $l$, a concentration $N$ and an absorption cross-section $\alpha$ is expressed as:

$$
\tau_{g a s}=\exp [-N \alpha l]
$$

Equation 4 imposes an important limitation to any retrieval procedure. Since the transmittance of any layer depends, for each gas species, on the product $N \alpha l$, called the column density, this product remains indivisible. For this reason, the results are quoted in path length units or $p p m \times m[6]$.

Assuming spherical symmetry of the plume it is possible to estimate local concentrations in units of $\mathrm{ppm}$. Knowing the nature of the gas, its extent as well as the specifics of the camera (field-of-view, distance to the gas plume), the concentration results can be expressed as total gas mass in units of grams.

\section{Results}

A typical quantitative detection report generated by the Hyper-Cam LW is given in Fig. 4. The detection report shows the black and white broadband infrared image of the scene with colored pixels superimposed to indicate detection of the compound of interest (SF6 for this measurement campaign). We can see that despite the low wind speed conditions, we are still able to observe some amount of spatial separation between subsequent gas puffs. The report also shows various measurement parameters including measurement date and time, GPS coordinates and bearing of the aircraft, and physical dimensions represented by the image. Additionally, the detection report displays information about the detection as well including the number of pixels containing the signature of interest, the physical dimensions of the detected gas cloud, and the quantity of gas detected in grams.

The compiled quantitative results of the measurement campaign are given in Tab. 1. Prior to the measurement campaign, Telops established an acceptance criterion stating that a quantification would be deemed successful if the total quantity of gas determined by the quantification algorithms

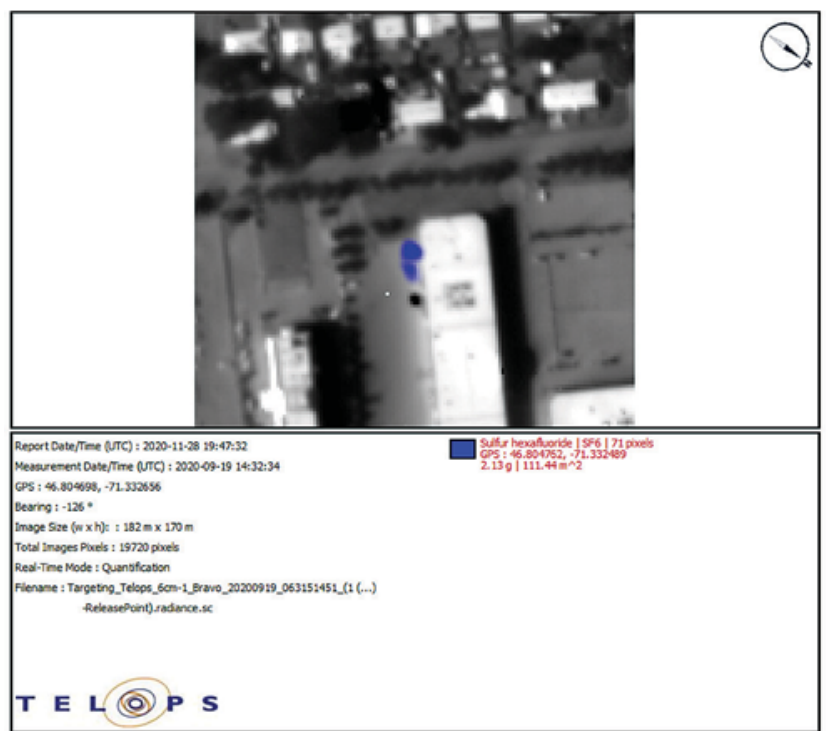

Fig. 3. Hyper-Cam LW detection report showing spatial distribution of detected SF6 and total gas quantity

Rys. 3. Raport z detekcji Hyper-Cam LW pokazujący rozkład przestrzenny wykrytego SF6 i całkowitą ilość gazu was within an order of magnitude of the total gas released in a single puff. Two separate quantification algorithms were employed for data analysis. The "Live Quantitation" column represents the quantitative results generated by the real-time quantification algorithm while the "Improved Model Quantitation" column represents the quantitative results generated by an improved algorithm applied in post-processing. The algorithms are described in paper [7] and are based on cloud detection using SMF filters, clustering-based selected-band method and then through a spectral smoothness algorithm on a homogeneous subimage to estimate atmospheric profiles (temperature, water vapor), surface emissivity, and surface temperature gas concentration estimation is determined.

Tab. 1. Compiled quantitative results from selected analysis Tab. 1. Zestawienie wyników ilościowych z wybranych testów

\begin{tabular}{|c|c|c|c|c|}
\hline Test & $\mathbf{1}$ & $\mathbf{2}$ & $\mathbf{3}$ & $\mathbf{4}$ \\
\hline Mission Type & $\begin{array}{c}\text { Targeting } \\
6 \mathrm{~cm}^{-1}\end{array}$ & $\begin{array}{c}\text { Targeting } \\
6 \mathrm{~cm}^{-1}\end{array}$ & $\begin{array}{c}\text { Targeting } \\
6 \mathrm{~cm}^{-1}\end{array}$ & $\begin{array}{c}\text { Mapping } \\
6 \mathrm{~cm}^{-1}\end{array}$ \\
\hline $\begin{array}{c}\text { Quantity Released } \\
\text { Real-Time }\end{array}$ & $\begin{array}{c}2.5 \mathrm{~g} / \mathrm{puff} \\
4 \mathrm{pufs}\end{array}$ & $\begin{array}{c}6.8 \mathrm{~g} / \mathrm{puff} \\
4 \mathrm{puffs}\end{array}$ & $\begin{array}{c}1.1 \mathrm{~g} / \mathrm{puff} \\
2 \mathrm{puffs}\end{array}$ & $\begin{array}{c}1.9 \mathrm{~g} / \mathrm{puff} \\
3 \mathrm{puffs}\end{array}$ \\
\hline $\begin{array}{c}\text { Quantitation [g] } \\
\text { Rusference Between }\end{array}$ & $2.15-2.23$ & $2.4-3.82$ & No & 0.3 \\
\hline $\begin{array}{c}\text { Measurement and } \\
\text { Release [\%] }\end{array}$ & $11-14$ & $44-65$ & - & 84 \\
\hline $\begin{array}{c}\text { Improved Model } \\
\text { Quantitation [g] }\end{array}$ & $0.90-2.13$ & $1.77-3.79$ & 0.19 & 0.34 \\
\hline $\begin{array}{c}\text { Measurement and } \\
\text { Release }\end{array}$ & $15-64$ & $44-74$ & 83 & 82 \\
\hline
\end{tabular}

The first three columns of Tab. 1 represent data acquired with the Hyper-Cam operating in targeting mode with a spectral resolution of $6 \mathrm{~cm}^{-1}$. Targeting mode makes use of the airborne platform pointing mirror to allow the Hyper-Cam to dwell on a specific target and collect additional hypercubes for data quality improvement. For Tests 1 and 2, both the realtime quantitation and the post-processing improved quantitation algorithms yielded results within the acceptance criteria established prior to the measurement campaign. For test 2, the gas concentration was determined with more error due to the change in prevailing weather conditions: it increased the wind speed by $25 \%$ compared to test 1 . For Test 3 , the real-time quantitation algorithm was unable to detect the released gas. Test 3 involved releasing 1.1 grams of SF6 per puff which is the lowest quantity tested during this measurement campaign. There are many factors that may contribute to the real-time non-detection including local wind conditions and Hyper-Cam detection limits, and these experimental factors are the focus of future development work. Nevertheless, despite the failure to detect and quantify in real-time, the post-processing improved quantitation algorithm was able to successfully detect and quantify SF6 within the acceptance criteria.

Test 4 represents data acquired with the Hyper-Cam operating in mapping mode with a spectral resolution of $6 \mathrm{~cm}^{-1}$. When operating in mapping mode, the airborne platform pointing mirror tracks consecutive ground patches with 
a given swath width and hypercubes are acquired as the aircraft travels. Mapping mode allows for the creation of hyperspectral maps over large areas, but does not allow the user to dwell over a specific target for improved data quality like Targeting mode. Despite the expected decrease in data quality, both the real-time and post-processing quantitation algorithms were successfully applied to the collected hyperspectral data. Both algorithms were able to generate quantitation results within an order of magnitude of the total gas released, which is encouraging given the low mass of $1.9 \mathrm{~g}$ per puff.

\section{Conclusions}

Telops Hyper-Cam Airborne platform is a well-established tool for large-are gas detection, identification, and quantification tasks. The Fall 2020 measurement campaign successfully demonstrated the performance of both a real-time and a post-processing algorithm in retrieving accurate gas concentration values from samples generated by a validated gas release system. For this measurement campaign, a successful analysis was defined as one in which the quantitation algorithm yielded a total gas quantity within an order of magnitude of the gas quantity released. The real-time quantitation algorithm was able to generate a successful analysis for three out of four total tests, with the lone unsuccessful analysis coming on the lowest released concentration. The Improved Model post-processing algorithm generated four out of four successful tests. These results demonstrate the utility of Telops aerial thermal infrared hyperspectral imaging platform for gas detection, identification, and quantification. Future research directions include optimizing the quantitation algorithms for use with the Hyper-Cam Airborne Mini which allows for deployment on a significantly expanded set of aerial platforms.

\section{References}

1. Kastek M., Piatkowski T., Dulski R., Chamberland M., Lagueux P., Farley V., Method of gas detection applied to an infrared hyperspectral sensor, "Photonics Letters of Poland", Vol. 4, No. 4, 2012, 146-148, DOI: 10.4302/plp.2012.4.09.

2. Chamberland M., Lagueux P., Tremblay P., Savary S., Gagnon M.-A., Kastek M., Piątkowski T., Dulski R., Standoff gas detection, identification and quantification with a thermal hyperspectral imager, "WIT Transactions on Ecology and the Environment", Vol. 181, 2014, 671-682, DOI: $10.2495 /$ EID140571.

3. Rutkowski R., Kastek M., Madura H., Sosnowski T., Multi-function analysis of hyperspectral data, "Measurement Automation Monitoring", Vol. 63, No. 2, 2017.

4. Kastek M., Piątkowski T., Trzaskawka P., Infrared imaging Fourier transform spectrometer as the stand-off gas detection system, "Metrology and Measurement Systems", Vol. 18, No. 4, 2011, 607-620, DOI: 10.2478/v10178-011-0058-4.

5. Chmiel M., Kastek M., Całus D., Szczepański K., Thermovision and spectroradiometry in stand-off detection of chemical contamination, "Environmental Protection and Natural Resources", Vol. 28, No. 3, 2017, 17-25,

DOI: $10.1515 /$ oszn-2017-0019.

6. Kastek M., Piątkowski T., Dulski R., Chamberland M., Lagueux P., Farley V., Hyperspectral imaging infrared sensor used for chemical agent detection and identification, 2012 Symposium on Photonics and Optoelectronics, DOI: 10.1109/SOPO.2012.6270545.

7. Idoughi R., Vidal T.H.G., Foucher P.Y., Gagnon M.A., Briottet X., Background Radiance Estimation for Gas Plume Quantification for Airborne Hyperspectral Thermal Imaging, "Journal of Spectroscopy", Vol. 2016, DOI: $10.1155 / 2016 / 5428762$.

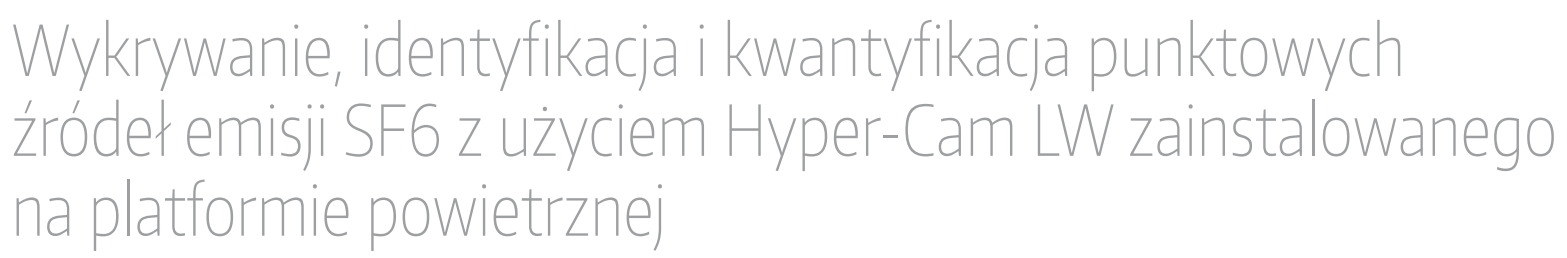

Streszczenie: Wykrywanie, identyfikacja i kwantyfikacja gazów cieplarnianych jest niezbędna do zapewnienia zgodności z wytycznymi regulacyjnymi i złagodzenia szkód związanych z antropogenicznymi zmianami klimatu. Technologia pasywnego obrazowania hiperspektralnego w podczerwieni należy do rozwiązań, które mogą wykrywać, identyfikować i kwantyfikować wiele gazów cieplarnianych jednocześnie. Platforma lotnicza Telops Hyper-Cam jest uznanym systemem do lotniczych pomiarów hiperspektralnych w termicznej podczerwieni do zastosowań związanych z badaniem gazów. W ramach wsparcia dla Hypercam, opracowywany jest zestaw algorytmów przetwarzania danych obrazowania hiperspektralnego, które pozwalają na wykrywanie, identyfikację i kwantyfikację gazów w czasie rzeczywistym. Jesienią 2020 r. platforma Hyper-Cam-LW Airborne została umieszczona nad zatwierdzonym systemem uwalniania gazu SF6 w celu zebrania danych hiperspektralnych do analizy kwantyfikacji gazu. Ta kampania pomiarowa została przeprowadzona w celu udokumentowania wydajności możliwości kwantyfikacji gazu Hyper-Cam w odniesieniu do znanych ilości uwolnionego gazu. 
Mariusz Kastek, PhD

mariusz.kastek@wat.edu.p

ORCID: 0000-0001-7184-5228

A graduate of the Electronics Department of the Military University of Technology (1993). Since 1997, he has been an employee of the Military University of Technology. He obtained the title of doctor of technical sciences in 2002. He deals with the problems of object detection in infrared systems, as well as signal analysis and detection algorithms implemented in infrared devices. Author and co-author of over 70 publications. He works as an assistant professor at the Institute of Optoelectronics of the Military University of Technology.

\section{Martin Lariviere-Bastien, PhD}

martin.lariviere-bastien@telops.com

ORCID: 0000-0003-0278-9431

Martin Larivière-Bastien holds an MSc in Nuclear Physics and a PhD in Computational Imaging from Université Laval. He is with Telops as an optical remote sensing specialist with specialization on infrared imaging Fourier transform spectrometer (FTS). His interests include the design of data processing and calibration tools for FTS as well algorithms for the detection, identification and quantification of substance from FTS measurement.

Krzysztof Firmanty, PhD

krzysztof.firmanty@wat.edu.pl

ORCID: 0000-0002-9124-6561

A graduate of the Electronics Department of the Military University of Technology (1993). Since 1993, he has been an employee of the Military University of Technology. He obtained the title of doctor of technical sciences in 2003. He deals with the problems of object detection in infrared systems, as well as signal analysis and detection algorithms implemented in infrared devices. Author and co-author of over 60 publications. He works as an assistant professor at the Institute of Optoelectronics of the Military University of Technology.

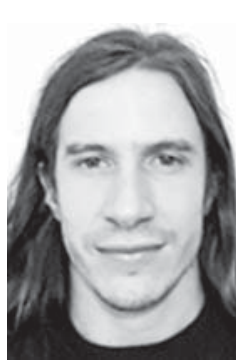

\section{Jean-Philippe Gagnon, MSc}

lean-philippe.gagnon@telops.com

Jean-Philippe Gagnon holds a master's degree in physics and worked at Telops since 2005. Since then, lean-Philippe has been involved in the development of their line of infrared cameras and hyperspectral infrared imagers. As a field applications scientist, lean-Philippe works with Defense and Security Labs, Industrial Labs and

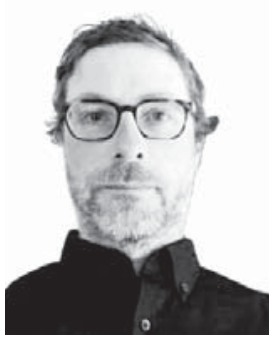

University Research Centers worldwide to perform measurement campaigns and support their data analysis efforts in a wide range of applications. More recently, he is part of the team using Telops' new miniaturized hyperspectral imager to quantify emissions from ship and thus help enforce \& control air pollution from ocean-going vessels.

\section{Daniel Pawelski, Eng}

biuro@technovis.p

ORCID: 0000-0003-2866-0011

A graduate (2005) of the Faculty of Electronics,

Telecommunications and Informatics of the Gdańsk University of Technology. Daniel Pawelski has almost 20 years of experience in design and implementation of defence systems in the field of radio reconnaissance and optoelectronics. He has been involved in commercial pro-

jects and scientific research for the medicine, army, police and border guards Currently, his work is focused on the use of computer vision and Al techno logies in thermographic and multispectral imaging.

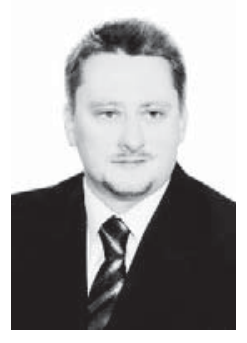

